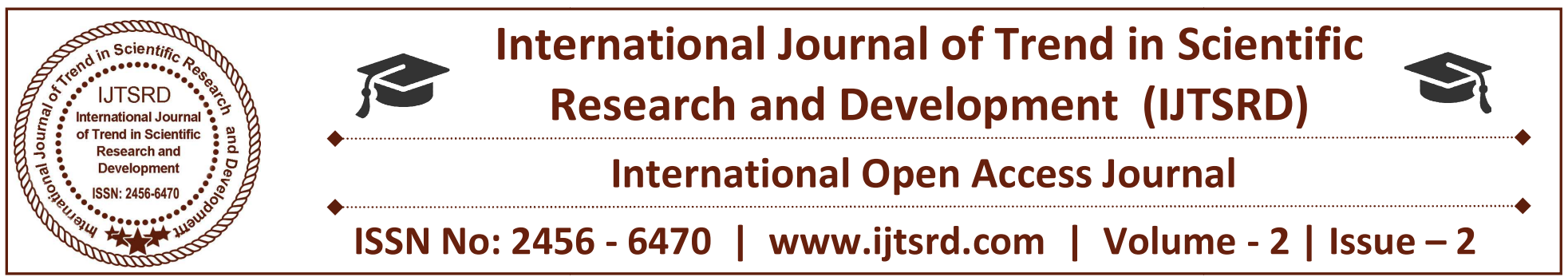

\title{
Effect of Select Demographic Variables on the Purchase Decision of Khadi Cloth
}

Dr. Veena Jha

Asst. Professor, Department of Commerce, Shri Cloth Market Institute of Professional Studies (SCMIPS), Indore, Madhya Pradesh, India

\author{
Dr. Alok Bansal \\ Professor, Prestige Institute of Management and \\ Research, Indore, Madhya Pradesh, India
}

\section{ABSTRACT}

Credit goes to our national father Gandhiji in making khadi apparel popular amongst people. It never used to be decorative in the days of Gandhiji.But today it comes in different soothing color, comfortable textures. Khadi has a unique style and brand. The purpose of this research paper is to study the factors affecting the purchase decision of Khadi cloth and to see the effect of select demographic variables on these factors. An empirical study has been done in Indore division, involves 110 respondents to obtain the required data. The questionnaire result analyzed with SPSS which are Independent $\mathrm{T}$ test and One Way Anova in order to see that is there any difference of gender and age on the Purchase decision of Khadi Cloth. It was found that gender has its significant effect on the promotion, environmental and total factor of purchase decision of Khadi cloth, while age does not have its significant effect on the purchase decision of Khadicloth. This research also as an effort to help seller in having better performance in future market.

\section{Keywords: Khadi cloth, consumer behavior, purchase decision}

\section{Introduction}

The present study focuses on effect of select Demography on the purchase decision of Khadi cloth. With growing awareness, comfortable issue, influence from self-image and concern about environment, the number of consumers are increasing. This is highly lucrative and potential market and there is a need to explore this market due to its special features. The khadi Cloth is pre-dominate in metros, and Indore division is mini metro, so this research confined to Indore region.

Today, Khadi has become iconic apparel. Wearing Khadi has become a matter of pride. Textile designers have commercialized it Khadi glorifies our wardrobes .Fashion designers get innovative ideas to improve the texture of Khadi. If we compare Khadi with machine made cloth, we will find that it is better than it in so many ways .It is relatively more comfortable than machine made fabrics. Khadi is non allergic It enhances men personality.

\section{Factors affecting purchase of Khadi Cloth:-}

\section{Khadi product feature}

Product factor: Kotler (2006):-A product is anything that can be offered to a market to satisfy a want or need.Khadi is available in different prints and designs, so customers can have a bigrange for selection. It comes in different varieties Cotton Khadi,Silk Khadi, Woolen Khadi,Muslin Khadi,and Banga KhadiandPoly Khadi. We can have large variety of khadi clothes available in market whether stitched or unstitched like saris, kurtaas, dupattas, lehangaas, shirt pieces, jackets etc. It is interwoven in such a manner that it allows air circulation, which makes wearer feel cool in summer and warmth in winter. Its hand weaving attribute makes it a unique fabric that's why it is the most comfortable apparel for wearer. Its 
soft texture gives unusual feeling to wearer.Khadi requires starch which makes it wrinkle free, stopping from crushed. Khadi is a better option because it is durable,elegant,comfortable,eco-friendly,cool in summer and warm in winter. These qualities of khadi make it exclusive in textile field.

\section{Price factor:- Kothari (2011) According to} W.J.Stanton "Price is the amount of money which is needed to acquire a product."Apparently khadi seems costlier than machine made cloth. But when we think of durability, it lasts for 4-5 years and due to its quality, it is found that it is not so costly. Because of the extra ordinary look the modern generation prefers to wear khadi. Fashion conscious people and people live for values are interested in having different apparel and khadi fulfills their demand.

Promotion factor: -Kothari (2011) "Promotion is the communication by the marketer to its target customers regarding its product or services.It is a persuasive and informative factor which persuades people to purchase the product. If our product is superb also and offered at fair price too but cannot be sold unless and until people are not informed, influenced and persuaded. Same it is khadi clothes are promoted through fair and exhibitions, advertisements, window display and by giving time to time discount on purchases. To make people aware of khadi cloth, these can be the effective promotional tools.

Place/Availability factor: We mean the system of marketing channels through which products are and services are distributed to the ultimate consumers or final buyers. With the demand of product it is imperative it can be easily available to customers at right quantity, right time and right place. Availability factor affects the demand and supply of khadi cloth. Khadi cloth can be made available through khadi gram udyog, departmental store, retail store etc.

Social factor: -Social factors :( Kotler 2006) A consumer's behavior is influenced by such social factors as reference groups, family, social roles and statuses.A person's reference factor is which directly and indirectly influences people to purchase the thing. They expose an individual to new choice and product .Reference groups influences people to purchase decision of consumers .These groups can be its family, friends neighbor's, peer group, celebrity/politician, which strongly impels buying decision. At the same time buyer also belongs to many groups like clubs, association etc. His /her own position in each group is specified by his role and status which also influence the purchase decision of khadi fabric.

Environmental factor:-Debraj Datta \& Madhu Datta (2006) Environmental Factors:-Behavior always occurs within a situation. Situational influences involve both people and objects and the influences that are in the situation itself. Situational influences can be defined along five dimensions which are Physical surroundings, Socialsurroundings, Time, Task and Antecedent states (temporary mood or condition of the customer).Purchasing decision of Khadi clothalso depends on climatic condition also as it is woven in such a way it has ample amount of ventilation it soaks the sweat and keeps the body cool and dry .It is $100 \%$ body friendly andgood for all season. Its industry nonpolluting and do not harm nature in any manner it is eco-friendly. Fashion designers make it to put it on for special Occasion's too.

\section{Consumer behavior:-}

Kothari and Sharma (2009) Consumer behavior is a reaction of individuals in obtaining \& buying goods and services of a particular type .It is an orderly process whereby the customers(individuals interacts with his environment for making a purchase decision of products. It includes communication, purchasing\& consumption behavior.Consumer behavior consists of factors that have effect on buying. Consumer behavior consists of factors that have effect on consumer's buying decision.

Professor Walter C.G. \& Professor Paul C.W "the process whereby individuals decide whether, what, when, where, how and from whom to purchase goods and services."Consumer behavior deals with as to why and why not an individual purchases particular products and service. Consumer behavior as a studyfocuses on the decision process of the individual consumer or consuming unit. In contrast the consumption behavior as a study, is to do with the explanation of the aggregates of consumers or consuming units, either at a given point of time or over a period of time.

\section{Demographic variable:-}

Age \& stage in the life cycle:-People buy different goods and services over a life time. Taste in food, clothes, furniture and recreation is often age related. 
Consumption is also shaped by the family life cycle\& the number, age\& gender of people in the household at point in time.In our study we have taken the age group of 25-35years, 35-45years, 45years and above as they are employed and with a reasonable disposable income . Bose (2009)The India about 35 million and 25 million are employed in the government and organised sector respectively. The country is also the largest technical man power in the worldwith information technology ,computer and software technology and its people are the strongest and largest asset in the world. The Indian consumer spends 3.5\% on Clothing and Footwear .

\section{Sherlekar (2013) Basic Model of Consumer - Decision Making (Stimulus-Response Model) \\ Consumer decision making is composed of three} stages; i.e. Input, Process and Output

Input: - is stimulus variable and it includes marketing efforts of the organization and socio cultural environment. The efforts include 4P's of marketing, i.e. Product, Price\& promotion \& distribution network. The inputs are basically marketing mix components that consist of product, Packaging, Advertisement's Pricing of the product \& promotion $\&$ distribution channel to move the product from the place of production to the place of consumption i.e. the consumer.

The social -cultural environment serves as a non commercial source of information .It includes reference groups (friends, colleagues in the office, members of local club etc.) members of the family, social classes and cultural factors. These factors have tremendous influence on consumer.

Process -It deals with how consumer makes purchase decision. The consumer receives the inputs (marketing efforts and socio-cultural factors) and processes the inputs through psychological process of information processing. It includes problem recognition, information search, evaluation of alternatives and benefits that lead to a buying decision. The decision process which involves a number of complex variables is not visible to us.

Output- It consists of purchase behavior and post purchase behavior.

Sherlekar (2013) P.no 120 Purchase decision:Purchase decision includes decisions regard to product/brand, dealer, quantity and quality, timing and payment.

Literature Review: -Several researches has been done on the different aspects of Khadi.But very few researches has been done on factors affecting, so there are very few research and literature review on the subject related to Khadi cloth .Lots of studies has been done on purchasing decision. To be more precise if purchase decision of Khadi cloth is done concrete data can be found.

According to Mitchell and Walsh (2004), males and females want different products and they are likely to have different ways of liking and obtaining these. Gender has an important role in consumer be Consumer behavior. Because, the differences between men and women about expectation, want, need, lifestyle etc. reflect to their consumption behaviors (Akturan, 2009:66)

From the customers' perspective, products are viewed as a bundle of benefits, not attributes (Day 1990; Peter and Olson 1990). In other words, "customers are less interested in the technical features of a product or service than in what benefits they get from buying, using or consuming the product." (Hooley and Saunders 1993, p. 17) In a competitive market, in addition to their basic benefits, products usually have many other attributes, such as features, styles, symbolism, durability, quality, and related services. By designing products with combinations of these attributes, marketers try to attract consumers with particular consumption values.

Abdul Waheed et.al (2014) in his studies mentioned that there are seven independent variables which governs purchase behavior and that are age, education, income, zodiac sign, credit facility, marital status and price of the product. But they emphasized that income and education are the major determinants for the purchase decision as compared to other factors mentioned before.

According to Lolo IN (2011) on his research 'The influence of Marketing Mix towards customer decision-making to saving on PT Bank Mandiri Makassar', place has a significant influence towards customer decision-making at PT. Bank MandiriCabangKartini. 
According to Taylor and Wills (2000), psychology places a strong and large part in pricing a product. Consumers facing any risk in their purchasing decision feel safer with a price. The fact that a high price is an indicator of quality of a product is the consumer's perception. Price indicates some amount of money that needs to be paid to achieve something (Friedrich, 2004). Some products or services are purchased based on customer's perception of price instead of the actual money price. Price is classified into two parts that is objective price and perceive price .Objective price is the actual price of the product while perceive price is individual believe of the price in relation to the quality of the product(Donald R., Lichtenstein \& Scot B., 1989).

According to Swastha and Irawan (2008), promotional mix is information flows or one way persuasion which directing someone, people, or organization to make a demand. Promotional mix is used to expand and penetrate the market, build the company's image, provide information, increase and stabilize sales, add value to product and differentiate the products (Williamson, 2012)

Another research found that there is an impact of place towards customer buying decisionFadhillah AP (2013). On 'the analyze of product, price, promotion, and distribution towards customer buying decision'

Social factors affect consumer behavior significantly. Every individual has someone around influencing their buying decisions The important social factors are: reference groups, family, role and status. (Perreau, 2014.)

In fact, consumers have, in the past, expressed their demand for green products to companies (Bockman et al., 2009 and Schmeltz, 2012). Although the number of individuals willing to purchase green products has increased in the last few years, there is little evidence to suggest that purchase of green products has increased; despite environmental concern and positive attitude of customers towards sustainability and green products, market share of green products remains confined to just $1-3 \%$ of the entire market (Bray, Johns and Kilburn, 2011). This suggests that environmental considerations play a minor role in consumer purchasing decisions and people generally overlook environmental impacts of their purchases (Mohr, Webb and Harris, 2001).Padmasani, S. Muruganandan and M. Yazhini
(2012) concluded that the consumers have positive attitude towards khadi product and also that the consumers who have higher attitude get more satisfaction.

\section{Padmasani, Muruganandan ,and}

Yazhini M,(2012)finds that rural and urban customers not significantly differ in attitude and satisfactions towards Khadi product. Moreover, the attitude towards Khadi products has significant positive relationship with the customers' satisfaction.

Dr. P. K. Jain (2012) 'Khadi' is our national pride should now be recognized as 'National Fabric' 'National Flag', 'National Dress', 'Symbol of National Economy' and what not more, as dreamt by Mahatma Gandhi, our Father of the Nation. We do not lack manpower, natural resources, finances or infrastructure in our country however, we lack only will power. If it is brought on the way we can definitely bring our India once again on glittering globe ahead of Japan, Indonesia, Switzerland, Singapore, Malaysia and China even. We should try to revive it as 'Quality Khadi', out lost glory with full sincerity. It is hoped that Ministry of Micro, Small and Medium Enterprises (MMSMES) can play more effective and better role, in this direction

Research question: -This paper aims to find out the effect of independent variables (age and gender) on dependable variable (factors affecting purchase decision of Khadi cloth).

1. Does the gender have significant effect on the purchase decision of Khadi cloth?

2. Does the age have significant effect on the purchase decision of Khadi cloth?

Rationale of the study:-Most of the people think that wearing Khadi is like wearing any other kind of cloth. But it is not so, Khadi has some rationale value, as it is associated with our past history. The person who is wearing Khadi feel proud, glorious because it creates the feeling of nationalism, with that India is one of the largest exporting country of the world. . In the present competitive marketing scenario, marketers have to know everything they can know about consumers. Consumers of Khadi cloth have been seen to exhibit different buying behavior when they purchase Khadi cloth as compared to purchase of other cloth. So this makes it imperative that marketers must study effect of gender and age on purchase decision of Khadi cloth, so accordingly market segmentation can be 
done on this basis, they can make changes and flourish their market. It could help them in maintaining existing customers and making new customers.

Objectives of the study: -The following are the objectives of the study:-

1. To know the effect of gender on the purchase decision of Khadi cloth.

2. To know the effect of age on the purchase decision of Khadi cloth.

\section{Research Methodology:-}

The study: The study undertaken is exploratory in nature and based on survey method.

The sample: The study conducted in Indore city. In the study there are 110 respondents who are the consumer of Khadi Cloth (60 male and 50 female) with the age group of (25-35years, 35-45years, 45years and above) 47 respondents from $25-35 y$ years ,27 respondents from 35-45yearsand36 respondents from 45 years and above.

During the survey, 125 questionnaires were distributed to respondents in Indore city. Unfortunately 15 questionnaires were not responded appropriately. So the relevant data is from 110 responded questionnaires based on 5 point likert scale. The respondents were a mix demographic factors consisting of age and gender. Convenient and Judge mental technique was used to select the respondents.

Tool for Data collection: Primary data collected through self-designed questionnaire .It consisted 33 statements measured on 5 point Likert scale.The questionnaire begins with identification details of the respondent. It is divided into two parts. Part A consists about the respondent's general information, i.e. name, gender, age, occupation, income and education.

Part B consists of 33 statements about the effect of factors that influence your purchase decision of Khadi Cloth. All statements are on 5 point Likert scale. These factors are Product, Price, Promotion, Place, and Social and Environmental factor. Product Factor Affecting Purchase Decision of Khadi Cloth has 9 questions related to quality, texture, colors, Varieties, Durability, and Appearance, maintenance, available in both stitched and unstitched forms and comfortable with it in comparison to other Clothes.
Price Factor Affecting Purchase Decision of Khadi Clothes has 4 questions related to suitable according to its quality, expensive in comparison with others clothes, Price is never a barrier and prefer high priced Khadi Cloth for the sake of prestige. Promotional

Factor Affecting Purchase Decision of Khadi Cloth has 5 questions related to discounts/schemes, fair and exhibition, advertisements, window display and Fashion blogs. Place/Availability Factor Affecting Purchase Decision of Khadi Cloth has 5 questions related to easily available, available atKhadi gram store, boutique, and retail shops and from departmental store. Social Factor Affecting Purchase Decision of Khadi Cloth has 7 questions related to reference of Family, Friends, Celebrities/Politician endorsement, Neighbors reference affect my purchase decision, Peer Group, Social status, and Maintain self-image. Environmental Factor Affecting Purchase Decision of Khadi clothes has 3 questions related to wear it on special occasions, particular seasons and to save environment. The secondary data was obtained from reports, manuals, and different journals, publications for assessing existing findings, internet, books and documents.

Tool for Data Analysis: Total population of Indore is considered as finite were used for the study purpose. Statisticsused like frequency distributions, graphs, charts and inferential statistics like Independent $T$ test and One way Anova wasimplemented on the collected data The data entry and analysis was performed by using Microsoft Excel and Statistical Package for Social Science (SPSS) version (21.0).and following test were conducted.

In the study Independent $\mathrm{t}$ test, one way Anova is implemented on the collected data. T-test has been used to find out the significant effect of gender onthe purchasing decision of khadi cloth.

One way Anova has been used to find out the significant effect of age on the purchasing decision of khadi cloth.

\section{Normality}

Normality is used to determine whether the data population is normally distributed or not. In order to fulfill the criteria of using Independent $t$ test and One way Anova value should be normal distributed. In this study, the author used the normal distribution by using Probability P Plot. Available in Annexure 1 
One-Sample Kolmogorov-Smirnov Test was applied, whose value was found 0.650 , which shows normality of data.

Reliability Analysis had done using Cronbach's Alpha Method with reliability value- 0.708 ,

Hypotheses:-The following hypotheses are formulated to test their validity in the

Context of above objectives:-

H01:- There is no significant difference of the gender of customer on the product factor of purchase decision of Khadi cloth.

H02:- There is no significant difference of the gender of customer on the price factor of the purchase decision of Khadi cloth.

H03:- There is no significant difference of the gender of customer on the promotion factor of purchase decision of Khadi cloth.

H04:-. There is no significant difference of the gender of customer on the availability factor of purchase decision of Khadi cloth.

H05:-. There is no significant difference of the gender of customer on the Social factor of purchase decision of Khadi cloth.

H06:-. There is no significant difference of the gender of customer on the environmental factor of purchase decision of Khadi cloth.
H07:- There is no significant difference of the gender of customer on the total factor of purchase decision of Khadi cloth.

H08:-. There is no significant difference of the age of customer on the product factor of purchase decision of Khadi cloth.

H09:- There is no significant difference of the gender of customer on the price factor of purchase decision of Khadi cloth.

H010:-. There is no significant difference of the age of customer on the promotion factor of the purchase decision of Khadi cloth.

H011:- There is no significant difference of the age of customer on the availability factor of the purchase decision of Khadi cloth.

H012:- There is no significant difference of the gender of customer on the Social factor of purchase decision of Khadi cloth.

H013:- There is no significant difference of the age of customer on the environmental factor of purchase decision of Khadi cloth.

H014:- There is no significant difference of the gender of customer on the total factor of purchase decision of purchase decision of Khadi cloth.

\section{Results and Discussions}

Effect of Gender :-To study the effect of gender on purchase decision of Khadi cloth total 7 hypotheses were formulated.The results of hypotheses testing are as follows:-

\section{Hypothesis testing}

Table 1

\begin{tabular}{|l|l|l|l|l|l|l|l|}
\hline \multirow{2}{*}{ Hypothesis } & Male & \multicolumn{2}{|l|}{ Female } & \multicolumn{1}{l}{$\begin{array}{l}\text { T } \\
\text { value }\end{array}$} & $\begin{array}{l}\text { P. } \\
\text { Value }\end{array}$ & $\begin{array}{l}\text { Rejected/Not } \\
\text { Rejected }\end{array}$ \\
\cline { 2 - 8 } & Mean & $\begin{array}{l}\text { Std. } \\
\text { Deviation }\end{array}$ & Mean & $\begin{array}{l}\text { Std. } \\
\text { Deviation }\end{array}$ & & & \\
\hline H01 & 35.3000 & 4.75608 & 36.5800 & 3.87082 & 1.238 & .268 & Not Rejected \\
\hline H02 & 12.8000 & 2.65407 & 13.1800 & 2.21027 & 2.150 & .145 & Not Rejected \\
\hline H04 & 14.7667 & 3.37170 & 17.4800 & 2.40950 & 8.747 & .004 & Rejected \\
\hline H05 & 16.7833 & 2.45012 & 15.7600 & 2.66925 & 2.279 & .134 & Not Rejected \\
\hline H06 & 21.4500 & 3.61928 & 22.4400 & 3.69313 & .029 & .866 & Not Rejected \\
\hline H07 & 11.0000 & 1.94849 & 11.6000 & 1.29363 & 7.117 & .009 & Rejected \\
\hline
\end{tabular}


To see the effect of gender on purchasing decision of Khadi cloth, an independent sample test was conducted at level of significance (.05)

H01:-There is no significant difference of the gender of customer on the product factor of purchase decision of Khadi cloth an independent sample test was conducted asthevalue (.268) is more than level of significance (.05.). Today buyers whether it is male or female are only concerned with what the product does, what the product means to them and to what extent it satisfies their social and psychological needs.. As can be observed from the data, there was no significant difference between the men and the women in terms of data, so the hypothesis is not rejected. (Hooley and Saunders 1993, p. 17) In a competitive market, in addition to their basic benefits, products usually have many other attributes, such as features, styles, symbolism, durability, quality, and related services. By designing products with combinations of these attributes, marketers try to attract consumers with particular consumption values. Bose(2009)In India more and more women are getting into jobs, entrepreneurship and executive positions.

Women's movement:-Demand for products common to both the sexes become predominant

H02:- There is no significant difference of the gender of customer on the price factor of purchase decision of Khadi cloth it is not rejected as the $\mathrm{p}$ value (.145) is more than level of significance (.05).According to Taylor and Wills (2000), psychology places a strong and large part in pricing a product. Consumers facing any risk in their purchasing decision feel safer with a price. The fact that a high price is an indicator of quality of a product is the consumer's perception. So there is no effect of gender on price.as today both male and female go for the quality as compared to price.

H03:- There is no significant difference of the gender of customer on the promotion factor of purchase decision of Khadi cloth is rejected as the $\mathrm{p}$ value (.866) than level of significance (.05) Men and women consumers evaluate messages in advertisements differently. Marketing strategies differentiates gender buying behavior thus female are more emotional and easily be attracted by advertisements compared to male (Imam, 2013).

Kotler(2009)Nevertheless, men and women may respond differently to marketing messages. One study showed that women valued connections and relationships with family and friends and placed a high priority on people. Men, on the other hand, related more to competition and placed a high priority on action. Kotler P.no 169

H04:-. There is no significant difference of the gender of customer on the availability factor of purchase decision of Khadi cloth is not rejected as Khadi Cloth are easily available as its $p$ value (.134) is more than level of significance(.05).

H05:-. There is no significant difference of the gender of customer on the Social factor of purchase decision of Khadi clothis not rejected as now a days they are influenced by their groups equally.

H06:-. There is no significant difference of the gender of customer on the environmental factor of purchase decision of Khadi cloth rejected as the $p$ value (.009) is less than (.05).as male and female have different opinion about ecofriendly product, wear Khadi on different occasion and climate.

H07:- There is significant difference of the gender of customer on the total factor of purchase decision of Khadi cloth an independent sample test was conducted is rejected as the test revealed that isp value (.006) is less than (.05).the test revealed significant difference of the gender of customer on the total factor of purchase decision of Khadi cloth as According to Mitchell and Walsh (2004), males and females want different products and they are likely to have different ways of liking and obtaining these. Gender has an important role in consumer behaviors. Because, the differences between men and women about expectation, want, need, life-style etc. reflect to their consumption behaviors. This demographic variable is one that retailers consistently use as a means of classifying customer behavior (Marks 2002; Otnes and Mc Grath 2001). Researchers have demonstrated gender differences in terms of shopping preference and behavior for many years and despite the millennium marketers attempt to downplay gender differences, researches show that men's and women's shopping behavior differs on many levels. Men and women have been found to process information differently (Peter \& Olson 1999), relate to and value material possessions differently, purchase different items or different reasons (Dittmar et al. 1995, 1996). 
Effect of Age :-To study the effect of age on purchase decision of Khadi cloth total 7 hypotheses were formulated .The results of hypotheses testing are as follows:-

\section{Hypothesis testing}

Table 2

\begin{tabular}{|c|c|c|c|c|c|c|c|c|c|}
\hline $\begin{array}{l}\text { Hypothes } \\
\text { is }\end{array}$ & $\begin{array}{l}25-35 \\
\text { years }\end{array}$ & & $\begin{array}{l}35-45 \\
\text { years }\end{array}$ & & $\begin{array}{l}45 \text { years } \\
\text { and } \\
\text { above }\end{array}$ & & $\begin{array}{l}\text { F. } \\
\text { value }\end{array}$ & $\begin{array}{l}\text { p. } \\
\text { value }\end{array}$ & $\begin{array}{l}\text { Rejected } \\
/ \\
\text { Not } \\
\text { Rejected }\end{array}$ \\
\hline & Mean & $\begin{array}{l}\text { Std. } \\
\text { Deviatio } \\
\mathrm{n}\end{array}$ & Mean & $\begin{array}{l}\text { Std. } \\
\text { Deviation }\end{array}$ & Mean & $\begin{array}{l}\text { Std. } \\
\text { Deviation }\end{array}$ & & & \\
\hline H08 & 35.7447 & 4.14660 & 35.3704 & 4.47341 & 36.4444 & 4.72951 & .494 & .611 & $\begin{array}{l}\text { Not } \\
\text { Rejected }\end{array}$ \\
\hline H09 & 13.4255 & 2.18438 & 12.7407 & 2.47437 & 12.5556 & 2.74064 & 1.447 & .240 & $\begin{array}{l}\text { Not } \\
\text { Rejected }\end{array}$ \\
\hline $\mathrm{H} 10$ & 16.3830 & 2.86321 & 16.0000 & $3.31662 \mathrm{e}$ & 15.5000 & 3.69169 & .746 & .477 & $\begin{array}{l}\text { Not } \\
\text { Rejected }\end{array}$ \\
\hline H11 & 15.9149 & 2.87289 & 16.4444 & 2.18972 & 16.7500 & 2.46548 & 1.103 & .336 & $\begin{array}{l}\text { Not } \\
\text { Rejected }\end{array}$ \\
\hline H12 & 22.0851 & 3.15422 & 22.6667 & 4.54042 & 21.0833 & 3.51629 & 1.556 & .216 & $\begin{array}{l}\text { Not } \\
\text { Rejected }\end{array}$ \\
\hline H13 & 11.1489 & 1.68082 & $\begin{array}{l}11.2593 \\
\text { Intert }\end{array}$ & 1.55891 & J1.4444 & 1.85849 & .304 & .738 & $\begin{array}{l}\text { Not } \\
\text { Rejected }\end{array}$ \\
\hline H14 & 114.7021 & 9.56196 & 114.4815 & $10.58798 \mathrm{~S}$ & 113.7778 & 10.95996 & .085 & .918 & $\begin{array}{l}\text { Not } \\
\text { Rejected }\end{array}$ \\
\hline
\end{tabular}

ANOVA Results:-

Table - 2presents the results of analysis of variance for effect of age on purchase decision of Khadi cloth.

From the table 2 it is observed that effect of age on purchase factor with $\mathrm{P}$ value (.611),price factor(.240),promotion factor(.477) ,Place factor(.336),Social factor(.216) ,Environment factor(.738) and total factor (.918) is more than the significant F-value at 0.05 level which reveals that there is no significant effect of age on purchasing decision of khadi Cloth. Abdul Waheed et.al (2014) in his studies mentioned that there are seven independent variables which governs purchase behavior and that are age, education, income, zodiac sign, credit facility, marital status and price of the product. But they emphasized that income and education are the major determinants for the purchase decision as compared to other factors mentioned before.

Bipal .B.Bose (2009)Age :-However ,the demographic use for segmenting the market can lead to marketing operations on an un expected level, for ex:-Maggi noodles was launched to target the market of children and young population but it has been found to be liked by even adults.

Limitations of the study: Following are the limitations of the study they are as follows:-

- The study was limited to Indore city only.

- The study was confined to limited number of respondents it could be taken larger.

- The study is limited to Khadi cloth only, Khadi products could be taken for study.

Managerial Implications: This paper tries to throw light on effect of some specific factors ofKhadi cloth on consumer purchase decision. The research can help the business precisian's, entrepreneur and other related marketing Personnel in framing strategies related to decision for selling products. Further, it must be available in all types, so it can be wearable in all season and different occasions. Customer relationship management is built by marketer to hold existing customers for their required services. 
Promotions should be done through different methods to attract new customers. Awareness regarding its eco friendliness must be done.

If media is used more extensively for creating awareness about utilities of Khadi cloth with its benefits in focus, potential customers will grow much faster than they are growing today. It is comfortable to wear than machine made cloth and its eco-friendly are the key issues for potential customers. Retailers, departmental stores and khadi gram udyog sales men can be used for increasing awareness and promoting about Khadi Cloth. Proper window display, Advertisements through different media must be done to attract all segment.

The marketers has to see how change in its environment can lead to changing patterns of demand for its products .It also needs to access marketing opportunities and threats present in the surroundings.

Just as the human body may have problems, if it fails to adjust to environmental change, similarly business may fail if they do not adapt to external changes such as new sources of competition or changes in consumer's preferences.

In an ideal world, seller should know its customers so well that it is able to predict what they will require next, rather than wait until it is possibly too late and then follow.

\section{Conclusion:-}

The study has been done on six factors that influence purchase decision of customers. The first four factors are related to Marketing mix elements and other two factors are related to buyers characteristics.

The study found significant difference of gender on purchasing decision of Khadi Cloth.

The study found no significant effect of gender on product, price, place, social factors on purchasing decision of Khadi Cloth.

But there is a significant difference between male and female on promotion and environment factor. Thus promotion and environment are the two major factors which marketers must concentrate according to gender and basis of segmentation and marketers must target the customers' according to this segmentation.
The study found no significant difference of age on purchasing decision of Khadi Cloth as Khadi Cloth is available in different features price, promotion, available, for every age group. There is no significant difference of age on social and environment factor.

Customers are different in their purchase preferences. Consumers buy products for different reasons, they buy in different ways and use it differently. There is immense unevenness among consumers, so marketers need to understand their requirements and cater them effectively.

\section{References:-}

1. Sherlekar,S.A,and Krishnamoorthy (2013) Marketing Management concepts and cases .Himalaya Publishing House

2. Bose,Biplab.s.(2009) Marketing Management Himalaya Publishing House

3. Dutta ,Debraj and Datta,Mahua (2012) Marketing Management

4. Kumar,Arun and N.Meenakshi (2007) Vikas Publishing House Private Limited.

5. Kothari,Dr.Rakesh and Mehta,Dr.Anil (2011) Marketing Management Ramesh Book Depot

6. Kothari,Dr.Milind (2011) Principles of Marketing Ramesh Book Depot

7. Kotler,Philip (2002) Marketing Management Prentice Hall of India Private Limited

8. JunioAndreti, Zhafira Nabila H, Akmal Sheila S, Suresh Kumar (2013)The Analysis of Product, Price, Place, Promotion and Service Quality on Customers' Buying Decision of Convenience Store: A Survey of Young Adult in Bekasi, West Java, Indonesia.International Journal of Advances in Management and Economics| Vol.2 | Issue 6

9. MISHRA RAKESH,and JAIN DR. P. K. (2012 )THE RE-VITALIZATION OF KHADI - A NEED OF THE HOUR: A CASE STUDY AT SANGRUR (PUNJAB) VOLUME NO. 2, ISSUE NO. 5 (MAY) INTERNATIONAL JOURNAL OF RESEARCH IN COMMERCE, ECONOMICS \& MANAGEMENTfile://E:/case\%20studt.pdf

10. SondhiNeena andS.R. Singhvi S.R (2006)Gender Influences in Garment Purchase: An Empirical Analysis sage Journals http://gbr.sagepub.com/content/7/1/57.full.pdf + ht $\mathrm{ml}$ 
International Journal of Trend in Scientific Research and Development (IJTSRD) ISSN: 2456-6470

11. Padmasani, S. Muruganandanand M. YazhiniRURAL CONSUMERS' ATTITUDE TOWARDS KHADI PRODUCTS (2011) J ournal of Management and Sciencehttps://doaj.org/article/1868166fa6a64e99 89caf33317833248

12. Padmasani, S. Muruganandanand M. Yazhini A case study on attitude of rural and urban customers of khadi products(2012). Asian Journal of Research in Business Economics and Management Volume : 2, Issue : 9http://www.indianjournals.com/ijor.aspx?target $=\mathrm{i}$ jor: ajrbem $\&$ volume $=2 \&$ issue $=9 \&$ article $=020$

13. SoniNehaandVergheseManoj (2013)Impact of Sales Promotion Tools on Consumer's Purchase Decision towards White Good (Refrigerator) at Durg and Bhilai Regionof CG, India Research Journal of Management Sciences Vol 2

14. Eckman Molly LynnMary Damhorst and Sara J. Kadolph Toward a Model of the In-Store Purchase Decision Process: Consumer Use of Criteria for Evaluating Women's Apparel

15. Sage journals http://ctr.sagepub.com/content/8/2/13.short?rss $=1$ \&ssource $=\mathrm{mfc}$

16. Kothari, and Sharma, (2009). Title Journal Name, Vol. (No.), pp.

17. http://www.thehindu.com/features/metroplus/fashi on/proud-to-wear-khadi/article5630993.ece

18. divineray.com/blog/wear-khadi-products/

19. https://en.wikipedia.org/wiki/Khadi

20. http://www.mkgandhi.org/articles/khadi-a-clothand-beyond.html

21. www.mkgandhi.org/swadeshi_khadi/advantages

22. http://www.thehindu.com/features/metroplus/fashi on/proud-to-wear-khadi/article5630993.ece

23. http://khadicotton.blogspot.in/

24. http://www.managementparadise.com/forums/man agement-co-operatives/205004-types-khadi.html

25. http:/www.managementparadise.com/forums/man agement-co-operatives/204987-khadi-villageindustries-commission-kvic.html

26. http://www.slideshare.net/tanujpoddar/businesscase-prayas

27. http://www.rediff.com/money/interview/inter-usekhadi-to-beat-global-warmingwoes/20090821.htm

28. http://www.rediff.com/money/interview/inter-usekhadi-to-beat-global-warming-

29. http://shodhganga.inflibnet.ac.in/bitstream/10603/ 2719/16/16_chapter\%209.pdf

30.jms.nonolympictimes.org/Articles/2.pdf
31. homepage:

http://www.innovativejournal.in/ijbm/index.php/ij bm 100

32. www.innovativejournal.in

33. innovativejournal.in/ijbm/index.php/ijbm/article/d ownload $/ 35 / 30$

34. www.chandrakantalrks.org/khadi/HistoricalBackground-Khadi.htm

35. https://en.wikipedia.org/wiki/Khadi

36. www.mkgandhi.org/ebks/gandhijionkhadi.pdf http://dx.doi.org/10.1287/mksc.19.1.4.15178

37. V Trifts - Marketing science, 2000 pubsonline.informs.org

38. http://www.indiaprofile.com/fashion/khadi.htm

39.... - Clothing and Textiles ..., 1990 ctr.sagepub.com

40. V Trifts - Marketing science, 2000 pubsonline.informs.org

41. http://dx.doi.org/10.1287/mksc.19.1.4.15178

42. http://gbr.sagepub.com/content/7/1/57.short

43. www.ijrcm.org.in

44. http://en.mimi.hu/marketingweb/purchase_decisio n.html

45.www.mbaskool.com > Concepts > Marketing And Strategy

46. http://dictionary.cambridge.org/dictionary/english/ buying-decision

47. http://www.acrwebsite.org/volumes/7772/volumes /v22/NA-22

48. http://www.acrwebsite.org/volumes/7772/volumes /v22/NA-22

49. http://www.empgens.com/resources/PricePurchase-Decision.pdf

50. www.iiste.org/Journals/index.php/EJBM/article/vi ewFile/3919/3977

51. www.iiste.org

52. p://www.isca.in/IJMS/Archive/v2/i7/2.ISCARJMS-2013-057.pdf

53. http://www.isca.in/IJMS/Archive/v2/i7/2.ISCARJMS-2013-057.pdf

54. http://www.ijcrar.com/vol-2-9/Pinki\%20Rani.pdf

55. http://www.mkgandhi.org/articles/khadi-a-clothand-beyond.html

56. https://www.theseus.fi/bitstream/handle/10024/94 486/Lautiainen Tanja.pdf? sequence $=1$

57. https://whttps://www.theseus.fi/bitstream/handle/1 0024/94486/Lautiainen_Tanja.pdf?sequence=1

58. ww.theseus.fi/bitstream/handle/10024/94486/Laut iainen_Tanja.pdf?sequence

59. http://www.abhinavjournal.com/images/Commerc e_\&_Management/Sep12/1.pdf 
60. http:http://www.abhinavjournal.com/images/Com merce_\&_Management/Sep12/1.pdf

61. http://www.iracst.org/ijcbm/papers/vol4no22015/1 5vo14no2.pdf

62. //www.abhinavjournal.com/images/Commerce_\& Management/Sep12/1.pdf

63. http://www.sciencedirect.com/science/article/pii/S 2306774815000034

64. file://E:/gender\%20influence.pdf

65. https://doaj.org/article/1868166fa6a64e9989caf33 317833248

66. http://www.indianjournals.com/ijor.aspx?target=ij or:ajrbem \&volume $=2 \&$ issue $=9$ \&article $=020$

67. Bipal B.Bose (2009) "Marketing Management" Himalaya Publishing houses Marketing Management

68. Dr.Milind Kothari (2011) "Marketing Management" Ramesh Book Depot

69. Kotler "Marketing Management" (2006) PrenticeHall, Englewood Cliffs,UK. 